\title{
Geographical Distribution of Emergency Services Times in Traffic Accidents in Extremadura
}

\author{
José Antonio Morales-Gabardino ${ }^{a}$ Laura Redondo-Lobatob \\ João Meireles Ribeiro ${ }^{c}$ Francisco Buitrago ${ }^{d}$ \\ ${ }^{a}$ Emergency Medical Unit of Cabeza del Buey (Badajoz), Extremadura Health Service, Badajoz, Spain; ${ }^{b}$ Pueblonuevo \\ del Guadiana Health Center (Badajoz), Extremadura Health Service, Badajoz, Spain; ' Enzymology Group, \\ Department of Biochemistry and Molecular Biology and Genetics, Faculty of Medicine, University of Extremadura, \\ Badajoz, Spain; "La Paz" University Health Center, Extremadura Health Service, Faculty of Medicine, University of \\ Extremadura, Badajoz, Spain
}

\section{Keywords}

Emergency medical services - Emergency response units . Response time - Transport time - Road traffic accidents . Motor vehicles

\begin{abstract}
Objective: To analyze the response time and transport time taken by the emergency medical services (EMS), considering their urban or rural location, to attend traffic accident casualties that occurred in the different geographical areas of Extremadura (Spain) from 2012 to 2015. Methods: This was a cross-sectional study of the data recorded by the Emergency Response Coordination Center 112 (ERCC-112) from traffic accidents attended by EMS. Response time was defined as the time elapsed from the request-for-care receipt until arrival of the EMS at the accident scene, and transport time as that from leaving the scene until arrival to the referral hospital. Rural EMS were those based in locations where there is no hospital, and urban EMS those located in towns or cities with a hospital. Results: During the 4-year period studied, 5,572 traffic accidents requested assistance through the ERCC-112. From the 2,875 accidents (51.9\%) in which EMS
\end{abstract}

were mobilized, $55.4 \%$ occurred in urban roads and the remaining in interurban ones. A total of 113 people (mean age $48.4 \pm 19.0$ years, range $15-84$ years) died at the accident scene or before arrival to the hospital, $88.5 \%$ of them in interurban accidents. The average response time of urban and rural EMS was $10.7 \pm 7.3$ and $18.0 \pm 12.6 \mathrm{~min}(p<0.001)$, respectively, and the average transport time was $13.2 \pm 11.7$ and $45.2 \pm 25.0 \mathrm{~min}(p=0.009)$. Response time was longer than the 30-min optimum only in the most peripheral areas of Extremadura, while transport time exceeded the optimum of $90 \mathrm{~min}$ in the eastern regions of two health areas (Cáceres and Don Benito-Villanueva). 19.1\% of the victims attended by rural EMS were classified as having a serious prognosis or as having died, as compared with $11.2 \%$ ( $p=$ 0.048) of those attended by urban EMS. Conclusions: The geographical location of EMS in Extremadura (Spain) guarantees adequate response times in traffic accidents, both in rural and urban areas. However, recommended transport times were occasionally exceeded in the most peripheral areas, due to hospital location.

(c) 2021 The Author(s). Published by S. Karger AG, Basel on behalf of NOVA National School of Public Health
(C) 2021 The Author(s). Published by S. Karger AG, Basel on behalf of NOVA National School of Public Health

This is an Open Access article licensed under the Creative Commons Attribution-NonCommercial-4.0 International License (CC BY-NC) (http://www.karger.com/Services/OpenAccessLicense), applicable to the online version of the article only. Usage and distribution for commercial purposes requires written permission.
Correspondence to:

Francisco Buitrago, fbuitragor@gmail.com 
Distribuição geográfica dos tempos das urgências em acidentes de trânsito na Extremadura

\section{Palavras Chave}

Serviços médicos de emergência · Unidades de resposta a emergências - Tempo de resposta - Tempo de transporte . Acidentes de tráfico rodoviários · Veículos a motor

\section{Resumo}

Objetivo: Analisar o tempo de resposta e tempo de transporte dos Serviços Médicos de Emergência (EMS), dependendo da sua localização urbana ou rural, para atender vítimas de acidentes de trânsito que tiveram lugar nas diferentes áreas geográficas da Extremadura (Espanha), de 2012 a 2015. Métodos: Estudo transversal dos dados do Centro de Coordenação de Resposta a Emergências 112 (ERCC-112) sobre acidentes de trânsito atendidos pelos EMS. Definiuse tempo de resposta como o decorrido entre receção do pedido de auxílio e chegada do EMS ao acidente, e tempo de transporte como aquele entre saída do lugar do acidente e chegada ao hospital de referência. Consideraram-se EMS rurais aqueles situados em localidades sem hospital e EMS urbanos os localizados em vilas ou cidades com um hospital. Resultados: Durante os quatro anos estudados, 5,572 acidentes de trânsito solicitaram assistência através do ERCC-112. Dos 2,875 acidentes (51,9\%) em que foram mobilizados EMS, 55.4\% tiveram lugar em vias urbanas e os restantes em interurbanas. Faleceram 113 pessoas (idade média $48.4 \pm 19.0$ anos, amplitude 15-84 anos) no lugar do acidente ou antes da chegada ao hospital, $88.5 \%$ das quais em acidentes interurbanos. O tempo de resposta médio dos EMS urbanos e rurais foi $10.7 \pm 7.3$ e $18.0 \pm 12.6$ $\min (p<0.001)$ e o tempo de transporte médio $13.2 \pm 11.7$ e $45.2 \pm 25.0 \mathrm{~min}(p=0.009)$. O tempo de resposta superou o ótimo de 30 minutos só nas áreas mais periféricas da Extremadura, enquanto que o tempo de transporte excedeu o ótimo de 90 minutos nas regiões mais orientais de duas áreas de saúde (Cáceres e Don Benito-Villanueva). Das vítimas atendidas por EMS rurais, $19.1 \%$ foram classificadas como tendo prognóstico sério ou como tendo falecido, comparado com $11.2 \%$ ( $p=0.048)$ das vítimas atendidas por EMS urbanos. Conclusões: A localização geográfica dos EMS na Extremadura (Espanha) garante tempos de resposta em acidentes de trânsito adequados, tanto em zonas rurais como urbanas. Porém, os tempos de transporte recomendados foram às vezes superados nas regiões mais periféricas, devido à localização dos hospitais.

C 2021 The Author(s).

Published by S. Karger AG, Basel

Emergency Services Times in Traffic

Accidents

\section{Introduction}

Road traffic accidents are a public health problem and are the leading cause of accidental death in the world [1]. Motor vehicle collision is the top cause of death in the United States among persons aged 1-44 years [2]. In Europe, according to the last data published by the European Community (year 2019), the mortality rate was 51 per million inhabitants; in Portugal [3], the rate was 68 deaths per million, and in Spain they represent the fifth external cause of death, with 1,896 deaths in 2019 (38 deaths per million) [4].

In Extremadura, one of Spain's Autonomous Communities, in 2018 there were 1,455 traffic accidents with 51 fatalities, 40 of which $(78.4 \%)$ died in one of the 675 interurban accidents ( $46.4 \%$ of the total of accidents) [5]. In 2019 , again, the number of fatal victims was greater (78.0\%) in the 716 interurban accidents than in the 696 urban accidents (22.0\%), with a total of 50 victims in the 1,412 accidents that occurred that year [6].

There are many causes of traffic accidents, from the psychological and physical conditions of the driver to the characteristics of the vehicles, the weather conditions, or the type of road [7]. All of them can influence accident consequences; however, once an accident has occurred, the prognostic outcome of road accident victims depends, to a large extent, on the promptness and quality of care provided by the various healthcare structures.

In Spain, both health centers and local clinics, as well as more specialized health units, such as emergency medical services (EMS), participate in medical care for people involved in traffic accidents. In Extremadura, EMS are the units responsible for answering the sanitary emergencies and the calls considered urgent by the Emergency Response Coordination Center 112 (ERCC-112). Therefore, EMS play a vital role in the post-crash effort to reduce fatalities by providing first aid treatment and transportation to medical facilities [8]. Moreover, these EMS are also the units intended for assistance and urgent transport of other patients (people that suffered cerebrovascular accidents, acute ischemic cardiomyopathy episodes, cardiorespiratory arrests, etc.), which implies that there are many occasions when optimal care requires rapid intervention by EMS. All the above highlights that, in sanitary planning, it is important to know the time periods required for EMS arrival to the place where a traffic accident occurs (or a request for any other urgent assistance is issued) and the time periods for the transport of casualties or patients to the hospital.

Port J Public Health 2021;39:78-87

DOI: $10.1159 / 000519858$ 
This study aims to analyze the response time and transport time taken by the urban and rural EMS to attend casualties due to traffic accidents that occurred in the different geographical areas of Extremadura (Spain) from 2012 to 2015. A secondary objective is to address the seriousness of victims involved in those accidents.

\section{Methods}

The Autonomous Community of Extremadura, located in the west-central part of the country close to the Portuguese border, is made up of the two largest provinces of Spain: Badajoz $(21,766$ $\mathrm{km}^{2}$ ) and Cáceres $\left(19,868 \mathrm{~km}^{2}\right)$. Its population is 1,092,997 inhabitants and its population density is low (26.5 inhabitants $\left./ \mathrm{km}^{2}\right)$ [9]. It is divided into 8 health areas, 4 in the northern province of Cáceres (Cáceres, Coria, Plasencia and Navalmoral de la Mata) and 4 in the province of Badajoz (Badajoz, Mérida, Don Benito-Villanueva and Llerena-Zafra). The health services mobilized to attend traffic accidents are coordinated by the ERCC-112, which, depending on proximity, availability, and initial assessment of the seriousness, will mobilize the appropriate resources from local clinics, health centers, or EMS to provide initial care for the victims. EMS are the health structures responsible for dealing with the demands considered emergency or urgent by the ERCC-112. Currently, Extremadura has 16 EMS units, distributed as shown in Figure 1. For the purpose of this study, they were divided into rural EMS, those located in a town or city where there is no hospital (8 out of the 16 units), and urban EMS, those located in towns or cities where there is a hospital (the remaining 8 units). General population data were from the Spanish National Statistics Institute.

We performed a cross-sectional study of the information kept in the records of the Emergency Response Coordination Center 112 (ERCC-112) related to traffic accidents attended by EMS.

\section{Data Extraction}

The database with all the information on traffic accidents for the period 2012-2015 was provided by the management team of the ERCC-112 and part of its analysis has been published elsewhere $[10,11]$. The response time or reporting-scene time is defined as the time interval between the notification to ERCC-112 and the EMS arrival on the scene $[12,13]$. This time is comparable to the so-called medical response time in other studies $[14,15]$. The transport time is defined as the time from the moment of leaving the scene of the accident until the arrival of the EMS at the "useful" reference hospital (the hospital which can guarantee the care required by a given patient with severe trauma).

\section{Statistical Analysis}

Data analysis was performed cross-sectionally and stratified by year with the use of SPSS software (Statistical Package for Social Sciences), version 22.0 for Windows. For the unit of analysis "accident," the variables considered were: type of accident (urban, those that occur inside towns or cities; and interurban, those that occur outside, i.e. in interurban roads), response and transport times taken by the EMS, EMS mobilized to the accident, geographical location of the EMS (urban or rural), population covered by that EMS (EMS-area population), and population in the town or

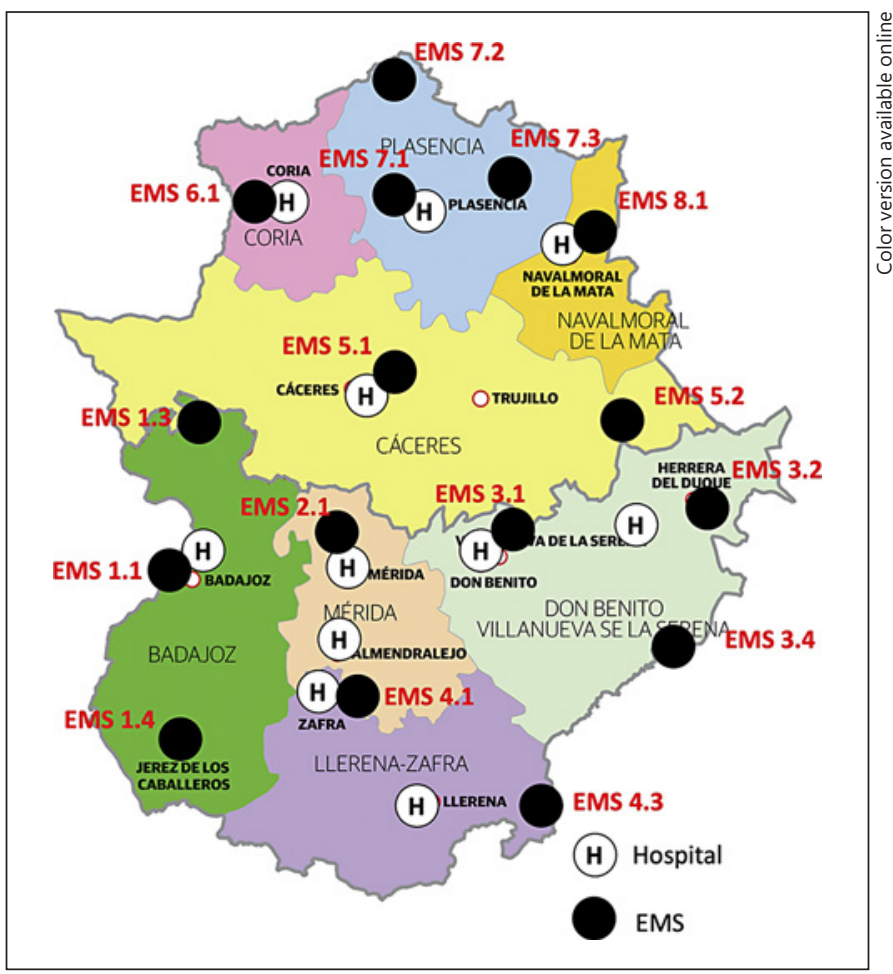

Fig. 1. Geographical distribution of emergency medical services (EMS) in Extremadura.

city where the EMS is located. For the unit of analysis "individuals involved in the accidents," the following variables were collected: age, in situ diagnosis made upon assistance and coded according to the International Classification of Diseases (ICD-9), and in situ assessment of the prognosis of casualties (not assisted, fair, less serious, serious, critical, and dead).

In bivariate analyses, a $t$ test for independent samples was conducted to compare the response and transport time of urban and rural EMS, and a $\chi^{2}$ test or Fisher's exact test was performed to compare the prognosis of casualties. Pearson's correlation coefficient was used to measure the correlation between the percentage of urban traffic accidents and the percentage of population in the town or city with an urban or rural EMS with respect to the total EMS-area population.

\section{Results}

A total of 5,572 traffic accidents requested assistance through the ERCC-112 during the 4 years studied. EMS were mobilized in 2,875 accidents, i.e. $51.9 \%$ of the total number of accidents, indicating that their action was requested in one out of every two traffic accidents. 55.4\% of these accidents occurred in urban roads and the remaining $44.6 \%$ in interurban ones. 
Table 1. Average response and transport times (4-year period analyzed) of the different Emergency Medical Services (EMS) and number of inhabitants covered by them

\begin{tabular}{|c|c|c|c|c|}
\hline & $\begin{array}{l}\text { Response } \\
\text { time }\end{array}$ & $\begin{array}{l}\text { Transport } \\
\text { time }\end{array}$ & $\begin{array}{l}\text { EMS area } \\
\text { population }\end{array}$ & $\begin{array}{l}\text { Population in the town } \\
\text { or city with EMS (\% } \\
\text { with respect to the EMS } \\
\text { area population) }\end{array}$ \\
\hline \multicolumn{5}{|l|}{ Rural EMS } \\
\hline EMS 1.3 San Vicente de Alcántara ${ }^{1}$ & $21.3(18.7)$ & $51.3(23.1)$ & 26,651 & $5,677(21.3 \%)$ \\
\hline EMS 1.4 Jerez de los Caballeros ${ }^{1}$ & $18.3(10.8)$ & $54.4(17.9)$ & 51,745 & $9,625(18.6 \%)$ \\
\hline EMS 3.2 Herrera del Duque ${ }^{1}$ & $19.2(12.7)$ & $35.7(20.0)$ & 21,585 & $3,691(17.1 \%)$ \\
\hline EMS 3.4 Cabeza del Buey ${ }^{1}$ & $16.6(9.5)$ & $54.1(26.2)$ & 22,927 & $5,136(22.4 \%)$ \\
\hline EMS 4.3 Azuaga ${ }^{1}$ & $17.7(14.2)$ & $25.2(13.6)$ & 24,497 & $8,035(32.8 \%)$ \\
\hline EMS 5.2 Cañamero ${ }^{2}$ & $17.9(10.1)$ & $76.4(33.1)$ & 12,459 & $1,707(13.7 \%)$ \\
\hline EMS 7.2 Caminomorisco ${ }^{2}$ & $19.9(12.6)$ & $59.5(18.0)$ & 8,503 & $1,267(14.9 \%)$ \\
\hline EMS 7.3 Jaraíz de la Vera² & $14.8(9.9)$ & $34.0(19.1)$ & 19,413 & $6,484(33.4 \%)$ \\
\hline \multicolumn{5}{|l|}{ Urban EMS } \\
\hline EMS 1.1 Badajoz city ${ }^{1}$ & $9.3(5.6)$ & $10.5(10.3)$ & 210,370 & $149,994(71.3 \%)$ \\
\hline EMS 2.1 Mérida ${ }^{1}$ & $9.7(6.7)$ & $13.6(8.8)$ & 137,113 & $58,959(43.0 \%)$ \\
\hline EMS 3.1 Don Benito ${ }^{1}$ & $12.1(8.6)$ & $11.7(8.5)$ & 107,734 & $36,953(34.3 \%)$ \\
\hline EMS 4.1 Zafra ${ }^{1}$ & $15.0(8.1)$ & $17.8(16.5)$ & 109,578 & $16,875(15.4 \%)$ \\
\hline EMS 5.1 Cáceres city ${ }^{2}$ & $8.9(6.9)$ & $9.9(8.8)$ & 155,227 & $95,620(61.6 \%)$ \\
\hline EMS 6.1 Coria ${ }^{2}$ & $15.8(10.0)$ & $18.0(14.4)$ & 47,408 & $13,037(27.5 \%)$ \\
\hline EMS 7.1 Plasencia ${ }^{2}$ & $12.7(8.6)$ & $15.3(12.1)$ & 91,031 & $40,782(44.8 \%)$ \\
\hline EMS 8.1 Navalmoral de la Mata² & $12.6(8.4)$ & $15.6(12.1)$ & 46,756 & $17,159(36.7 \%)$ \\
\hline
\end{tabular}

Times are expressed in minutes, mean (standard deviation). ${ }^{1}$ EMS in the province of Badajoz. ${ }^{2}$ EMS in the province of Cáceres.

Traffic accidents accounted for a total of 113 deaths, with victim mean age of $48.4 \pm 19.0$ years (range 15-84 years). An $88.5 \%$ of the victims (100 people) resulted from interurban accidents and $11.5 \%$ (13 people) from urban accidents. $42.5 \%$ of the deaths occurred in the accident scene or during the transport period, before arrival to the hospital.

The average response and transport times of urban and rural EMS in Extremadura, for the 4-year period analyzed, are shown in Table 1 . The average response time was $18.0 \pm 12.6 \mathrm{~min}$ in the rural EMS group and $10.7 \pm$ 7.3 min in the urban EMS group $(p<0.001)$; and the average transport time was $45.2 \pm 25.0 \mathrm{~min}$ in rural EMS and $13.2 \pm 11.7 \mathrm{~min}$ in urban EMS $(p=0.009)$. The average response and transport times, for each year and each EMS, are shown in the online supplementary Table (see www.karger.com/doi/10.1159/000519858 for all online suppl. material). These values show high variability; no global trend was observed during the period analyzed.

Response and transport times were longer in interurban accidents than in urban ones: $16.9 \pm 9.2$ versus $8.4 \pm$ 6.1 and $25.7 \pm 20.4$ versus $11.5 \pm 14.4 \mathrm{~min}(p<0.001)$, re- spectively. Response and transport times were also longer in accidents with fatal victims than in those without deaths, with mean values of $18.8 \pm 7.7$ versus $12.2 \pm 8.8 \mathrm{y}$ $27.2 \pm 16.2$ versus $19.5 \pm 19.4 \mathrm{~min}(p<0.001$ in both comparisons).

There was a higher percentage of urban traffic accidents in the areas with a greater percentage of population in the town or city where the EMS is located (with respect to the total EMS area population). Actually, a linear relationship was observed between the percentage of urban accidents and the percentage of population in the town or city with an urban EMS (Fig. 2a), with a Pearson correlation coefficient of $0.904(p<0.001)$. However, no significant relationship was found between the percentage of urban accidents and the percentage of population in the town with a rural EMS (Pearson correlation coefficient of $0.332, p=0.442$; Fig. $2 b$ ).

A $19.1 \%$ of the 623 casualties attended to by rural EMS were classified as having a serious/critical prognosis or as having died, as compared with $11.2 \%$ of the 2,545 casualties attended by urban EMS $(p=0.023)$. 


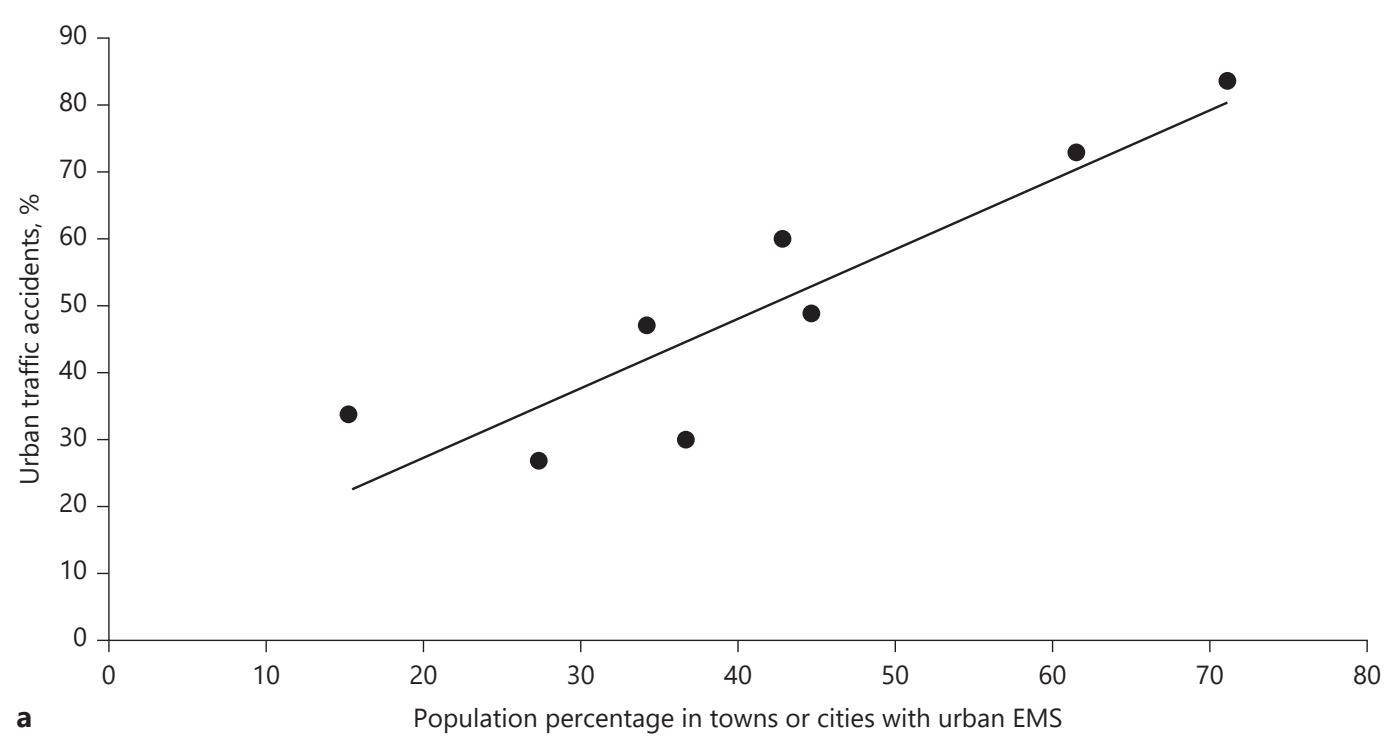

a

Population percentage in towns or cities with urban EMS

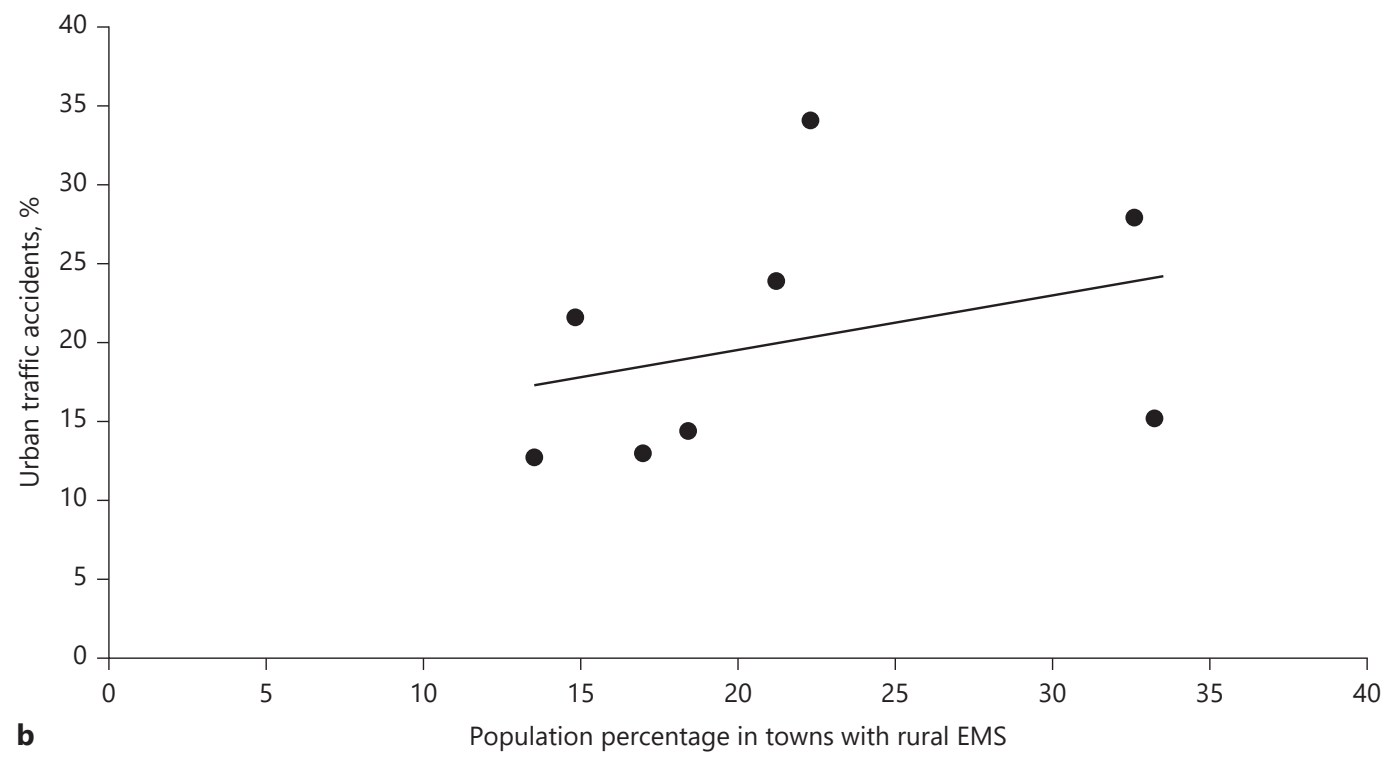

Fig. 2. Relationship between the percentage of urban traffic accidents and the percentage of population in towns or cities with urban emergency medical services (EMS) (a) or rural EMS (b) with respect to the total EMS-area population.

Regarding the type of lesions suffered by the injured people, the greatest number corresponded to multiplelocation contusions and traumas (1,699 diagnosis, 49.7\% of the total), followed by fractures (499 cases, $14.6 \%$ ), and wounds and erosions (472 cases, $13.8 \%$ ). It is also worth mentioning that 44 of the injured (1.3\%) were in a situation of ethylic intoxication at the moment of the accident, and 3 suffered some type of cerebrovascular ictus before the traffic accident.
An analysis of trauma types according to the type of accident (urban or interurban) showed that the most serious injuries occurred in interurban accidents. Thus, $77.9 \%$ of abdominal traumas, $80.0 \%$ of pneumothorax, $88.9 \%$ of vertebral compression fractures, $61.9 \%$ of craniofacial fractures, $62.2 \%$ of thoracic fractures, and $65.0 \%$ of lower limb fractures, occurred in interurban accidents. 
Table 2. Casualties with serious/critical prognosis and dead attended by urban and rural EMS according to the type of accident

\begin{tabular}{|c|c|c|c|}
\hline & $\begin{array}{l}\text { Interurban accident } \\
\text { casualties } \\
n \text { (\% of total) }\end{array}$ & $\begin{array}{l}\text { Urban accident } \\
\text { casualties } \\
n \text { ( } \% \text { of total) }\end{array}$ & $p$ value \\
\hline \multicolumn{4}{|l|}{ Urban EMS } \\
\hline EMS 1.1 Badajoz city ${ }^{1}$ & $34(26.4)$ & $32(5.4)$ & $<0.001$ \\
\hline EMS 2.1 Mérida ${ }^{1}$ & $24(17.5)$ & $9(4.5)$ & $<0.001$ \\
\hline EMS 3.1 Don Benito ${ }^{1}$ & $31(17.7)$ & $18(11.8)$ & 0.201 \\
\hline EMS 4.1 Zafra ${ }^{1}$ & $33(15.9)$ & 11(10.7) & 0.274 \\
\hline EMS 5.1 Cáceres city² & $17(13.0)$ & $14(4.1)$ & 0.007 \\
\hline EMS 6.1 Coria $^{2}$ & $13(16.5)$ & $0(0)$ & 0.084 \\
\hline EMS 7.1 Plasencia ${ }^{2}$ & 27 (19.9) & $7(5.6)$ & 0.004 \\
\hline EMS 8.1 Navalmoral de la Mata² & $12(10.9)$ & $3(6.8)$ & 0.479 \\
\hline \multicolumn{4}{|l|}{ Rural EMS } \\
\hline EMS 1.3 San Vicente de Alcántara ${ }^{1}$ & $14(20.6)$ & $4(19.0)$ & 0.857 \\
\hline EMS 1.4 Jerez de los Caballeros ${ }^{1}$ & $23(25.0)$ & $2(13.3)$ & 0.632 \\
\hline EMS 3.2 Herrera del Duque ${ }^{1}$ & $7(58.3)$ & $1(2.0)$ & $<0.001$ \\
\hline EMS 3.4 Cabeza del Buey & $10(22.2)$ & $4(17.4)$ & 0.945 \\
\hline EMS 4.3 Azuaga ${ }^{1}$ & $22(34.9)$ & $8(33.3)$ & 0.922 \\
\hline EMS 5.2 Cañamero ${ }^{2}$ & $10(23.8)$ & $1(16.7)$ & 0.752 \\
\hline EMS 7.2 Caminomorisco ${ }^{2}$ & $3(7.5)$ & $0(0)$ & NA \\
\hline EMS 7.3 Jaraíz de la Vera² & $10(9.19)$ & $0(0)$ & NA \\
\hline
\end{tabular}

Percentage values were calculated with respect to the total number of casualties attended by each EMS in accidents of each type (interurban or urban). ${ }^{1}$ EMS in the province of Badajoz. ${ }^{2}$ EMS in the province of Cáceres. NA, not applicable.
The comparison between dead plus serious/critical casualties in urban and interurban accidents is presented in Table 2. The data indicated that the percentage of fatal victims and individuals with worse prognosis was higher in accidents attended to by rural EMS. They also suggest that patients who suffered an interurban accident have a slightly higher morbimortality rate.

Figure 3 shows the map of Extremadura with the average response times by geographical areas where road accidents occurred in the 4 years of the study. The distribution of the range of colors clearly shows how the shortest response times $(0-10 \mathrm{~min})$ corresponded to the areas near towns or cities where EMS are located. On the other hand, the most peripheral areas of the region have the longest response times, i.e. more than 35 min.

Figure 4 shows the distribution of the average transport times required for the transfer of patients from the place of the accident to the useful reference hospital. It can be seen that transport times increase as the place of the accident moves away from the hospitals of the region, with the longest times in the north of the province of Cáceres (Las Hurdes region) and in the most eastern zones of the provinces of Cáceres (Villuercas) and Badajoz (Helechosa de los Montes).

Emergency Services Times in Traffic Accidents

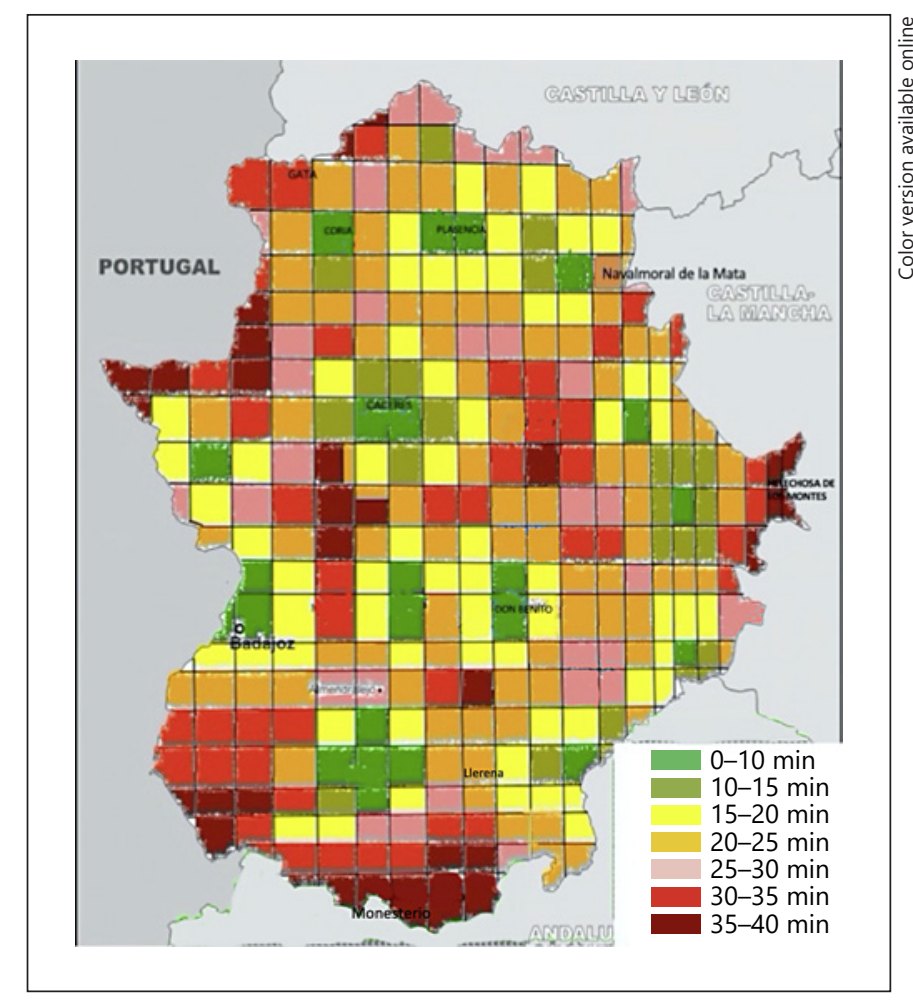

Fig. 3. Response times of emergency medical services by geographical areas in Extremadura.

Port J Public Health 2021;39:78-87 


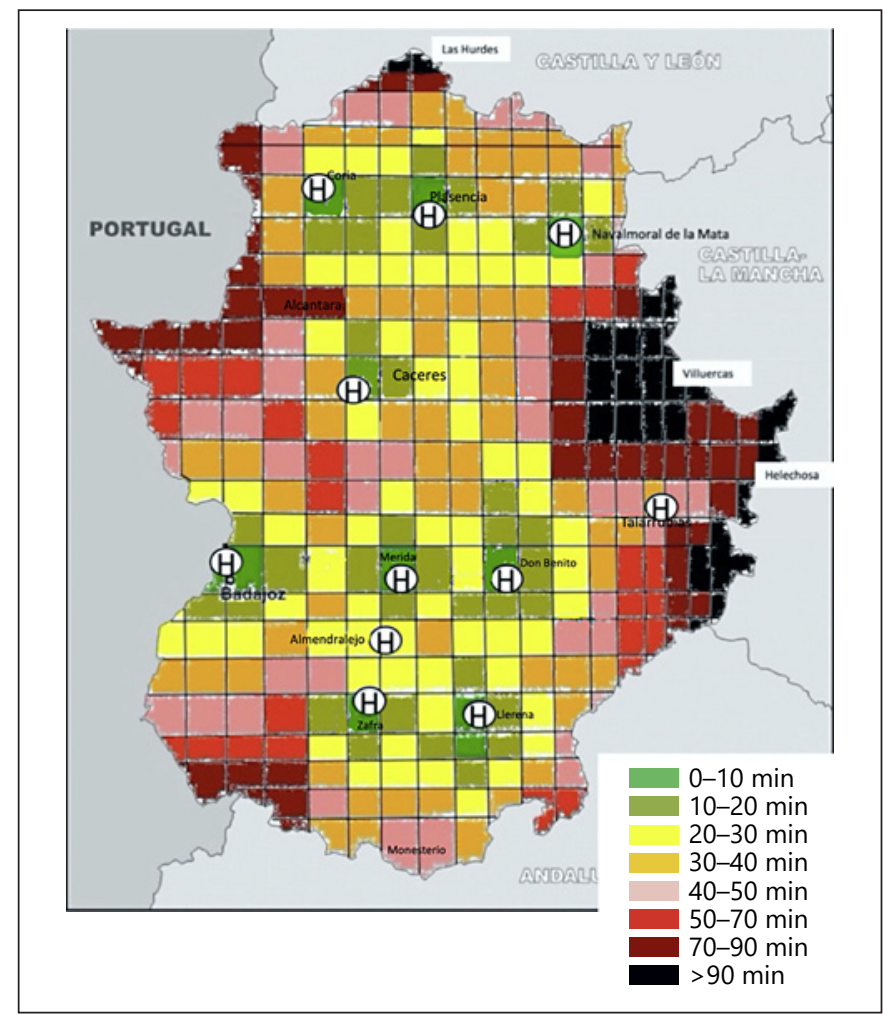

Fig. 4. Transport times of emergency medical services by geographical areas in Extremadura.

\section{Discussion}

The findings from our study indicate that the response and transport times taken by the EMS were longer in interurban accidents, which are the type of accident with the highest fatality rate and with casualties with greater severity and worse prognosis. They also indicate that a linear correlation exists between the number of urban accidents assisted and the number of inhabitants of the town where an EMS is located.

Our results, with response times of 10.7 and $18.0 \mathrm{~min}$ in urban and rural EMS, are similar to those obtained by Gonzalez et al. [16] (2009) in Alabama, which indicate times of 10.8 and $18.9 \mathrm{~min}$, also in urban and rural EMS, respectively. They are somehow larger than the average response times of 7.0 and $14.5 \mathrm{~min}$ reported in 2015 by Mell et al. [17] and the values of 7.8 and $14.0 \mathrm{~min}$ (overall mean, $10.5 \mathrm{~min}$ ) of the more recent study by Lee et al. [12] (2018), for traffic accidents in urban and rural areas, respectively.

Traffic accident victims need a quick assessment of the severity of their injuries and often require prompt care from EMS to improve their prognostic outcome [18]. The ability of EMS to quickly assist victims of traffic accidents (and also to patients who have suffered a stroke or heart attacks) depends, to a large extent, on having an adequate geographical location $[8,14,15,19,20]$.

The location of the EMS in Extremadura (Spain) guarantees victims of traffic accidents response times of less than $30 \mathrm{~min}$, except in the most peripheral areas of the region and in specific areas of the provinces of Cáceres and Badajoz. The shortest response times (0-10 $\mathrm{min})$ are located in areas close to towns or cities with an EMS, while the most peripheral zones (Helechosa de los Montes, Monesterio or the north of the Gata region) presented response times of more than $30 \mathrm{~min}$, which is considered to be the acceptable limit (Fig. 3) [12, 15, 16]. Traffic accident casualties who require EMS assistance from rural EMS are more susceptible to longer response times, due to the larger travel distances to a crash scene, because the majority of the patients attended by rural EMS are from interurban accidents, which occurred outside the town or city where the EMS is based. It should be noted that, in these accidents, the percentage of people with severe injuries was higher, and the transport times observed were also longer, which may have a greater impact on survival when compared to patients with similar injuries in an urban setting [21]. The percentages of population in towns or cities with EMS may explain, at least in part, the shorter response times and transport times in rural EMS 7.3 (Jaraíz de la Vera) and EMS 4.3 (Azuaga), which are the towns with EMS and with the highest percentage of population with respect to the total EMS area population (33.4 and 32.8\%, respectively; Table 1). However, the response time and the transport time are not always significant predictors of hospital mortality, while the Injury Severity Score (ISS) predicts mortality independent of scene time or transport time for patients who arrive to the hospital alive following a motor vehicle collision [13].

The average transport times of the EMS in Extremadura are also within the optimum range of less than $90 \mathrm{~min}$ $[7,11,14]$, except in the north of the province of Cáceres (Las Hurdes region) and in most eastern (Villuercas) regions of the health area of Cáceres (Fig. 4). In those regions, transport times are longer than in other areas in the north of the province of Cáceres (e.g., Navalmoral de la Mata, Plasencia, and Coria), probably because their distances to the reference hospital are larger and they have no freeway.

Transport times are obviously increasing as the accident site moves away from the hospitals, e.g. in Helechosa de los Montes or in Alia (at the far north of the Villu- 
ercas region) distant 135 and $142 \mathrm{~km}$ from their reference hospital (Don Benito and Cáceres, respectively). But the distribution of the range of colors also indicates that the hospital to which the casualties due to traffic accidents are eventually transferred may not always be the closest one. The reason is that some regional hospitals, as is the case of those in Almendralejo and Talarrubias, lack some services to be considered, depending on the type of injury, "useful" hospitals. And so, many patients from accidents occurring near these hospitals are transferred by the EMS to the reference hospitals of the health area, the hospital of Mérida and Don Benito-Villanueva, respectively. This is a quite different situation from that in the north region where there are three hospitals (Navalmoral de la Mata, Plasencia, and Coria) with surgical units able to attend casualties with less serious traumas, and which are connected by a freeway. The far northern region of Las Hurdes (Cáceres), with an average transport time of more than $90 \mathrm{~min}$, deserves a special comment. For traffic accidents occurring in this region, the actual transport time may double the average one, when the University Hospital of Badajoz is considered the "useful" hospital, as it occurs in accidents with casualties with serious cranioencephalic traumas, because it is the only hospital in Extremadura with a neurosurgery service.

In our study, $42.5 \%$ of the victims (48 of 113 deaths) died at the accident scene or before arrival to the hospital. According to Clark et al. [22], the majority of deaths caused by traffic crashes happen before the patient has arrived at the hospital, indicating that efficient EMS can reduce the impact of traffic crashes. Especially, EMS were shown to be effective in minimizing the fatality rates, and a 10-min reduction in the response time can decrease the probability of traffic fatalities by one-third [23].

This study has the limitations of works that analyze large databases, where the collection of information by different professionals may not be homogeneous. Furthermore, in ERCC-112 databases, the gender of casualties is not recorded. So, it is not possible to known if there is any difference in accident morbimortality related to gender, although in other published studies this variable is also often missing $[24,25]$. It was neither possible to gain access to the final evolution of patients, which would have made possible to know in a more exact way the morbimortality and the socioeconomic impact of traffic accidents in the studied region (Extremadura). This lack of casualty follow-up for sure causes an underestimation of the number of fatal victims, as the number of deaths reported here refers to the fatalities in the initial moment of care and before arrival at the hospital.

Emergency Services Times in Traffic Accidents
Another point that could be considered a limitation is the validity of the diagnosis and the prognostic recorded for the victims of traffic accidents. The former is dictated by the physician who attended to the victim, and it is communicated to the ERCC-112 operator; together, the physician and operator decide which ICD-9 code must be selected. However, this methodological approach, i.e. without later confirmation of the reliability of the reports dictated in situ, is usually followed in this type of studies [24-28]. Finally, it should be noted that other variables not recorded, for example severity of the accident, speed and number of vehicles involved, or difficulty in removing casualties from them, might be potential confounders, associated with interurban accidents and also with fatal accidents.

This study has also important strengths. The records analyzed are from the ERCC-112, a center for reception of request for help in urgency and emergency situations well known by the population, which gives an important representativeness to their data. It should be noted that the period studied ( 4 years) is wide enough, and the variables analyzed here [age, number of victims, type of accident (urban/interurban), time employed by the EMS to arrival at the site of the accident and to transfer the patient to hospital, diagnostic evaluation and casualty prognosis, and EMS mobilized] are data reported and collected compulsorily by the ERCC-112. Taken together, they constitute the main strengths of the study.

These results are also very useful to find out the efficiency and the rightness of the location of the different EMS, since the times needed to get to the accident site and to transfer the casualties to a hospital are also similar to those required for patients with pathologies such as myocardial infarction or stroke, where the delay in hospital care can worsen their prognosis. Nevertheless, the external validity of these results should be considered. First, although the EMS organization is similar in all Spanish National Health System, road characteristics and population density are different between autonomous communities. Second, the areas covered by each EMS also have quite different extension.

In summary, our study reveals that the location of the EMS in Extremadura makes it possible to guarantee response and transport times adequate for the majority of victims of traffic accidents, although there are areas where these times exceed the maximum accepted as optimal. So, EMS's response times and EMS's hospital times should be evaluated in future studies as a potential contributor to the seriousness of traffic accident casualties. Those longer times would depend not only on the communication routes and the great extension and geographical dispersion of our re- 
gion, but also on the location of the EMS and the tertiary hospitals that can treat all types of victims. The study also suggests that casualties due to traffic accidents attended to by rural EMS tend to have a worse prognosis than those attended to by urban EMS. Therefore, an adequate number and geographical distribution of EMS are key aspects of country's health policies to decrease casualties with permanent injuries and fatalities related to traffic crashes.

\section{Acknowledgements}

To the staff of the Extremadura Emergency Coordination Center 112 for their invaluable help in authorizing and facilitating the use of databases.

\section{Statement of Ethics}

The data were encrypted, and because of the anonymous nature of the database, it was not necessary to obtain informed consent, although approval of the study was given by the Director of Centro Coordinador de Urgencias y Emergencias 112 de Extremadura, D. Juan Carlos Gonzalez Rojo.

\section{Conflicts of Interest Statement}

The authors declare that they have not conflict of interest in relation to this article.

\section{Funding Sources}

None.

\section{Author Contributions}

J.A.M.G. and F.B. participated in the conception and design of the study, in the preparation of the databases, in the analysis and interpretation of the data, and in the writing and review of the manuscript. L.R.L. participated in the preparation of the databases and in the critical review of the draft with relevant contributions to the final version. J.M.R. participated in the interpretation of the data and in the preparation of the final version of the manuscript.

\section{References}

1 World Health Organization. Global Status Report on Road Safety 2015. Available at: https://www.who.int/violence_injury_prevention/road_safety_status/2015/en/.

2 Insurance Institute for Highway Safety. General statistics. 2016. Available at: http://www. iihs.org/iihs/topics/t/general-statistics/topicoverview.

3 European Commission. Mobility and transport. Road safety. Available at: https://ec.europa.eu/transport/road_safety/specialist/statistics_en.

4 INE. Instituto Nacional de Estadística. 2017. Notas de prensa. Defunciones según causa de muerte. Available at: https://www.ine.es/.

5 Las principales cifras de la Siniestralidad Vial España 2018. Available at: http://www.dgt.es/ Galerias/seguridad-vial/estadisticas-e-indicadores/publicaciones/principales-cifrassiniestralidad/Las-principales-cifras-de-laSiniestralidad-Vial-Espana-2018.pdf.

6 Las principales cifras de la Siniestralidad Vial España 2019. Available at: http://www.dgt.es/ Galerias/seguridad-vial/estadisticas-e-indicadores/publicaciones/principales-cifrassiniestralidad/Las_principales_cifras_de_la_ siniestralidad_vial_Espana_2019.pdf.

7 Smith AP. A UK survey of driving behaviour, fatigue, risk taking and road traffic accidents. BMJ Open. 2016 Aug;6(8):e011461.
8 Byrne JP, Mann NC, Dai M, Mason SA, Karanicolas $\mathrm{P}$, Rizoli $\mathrm{S}$, et al. Association Between Emergency Medical Service Response Time and Motor Vehicle Crash Mortality in the United States. JAMA Surg. 2019 Apr;154(4):286-93.

9 INE. Instituto Nacional de Estadística. 2015 Censo nacional y Comunidad Autónoma de Extremadura. Available at: https://www.ine. es/.

10 Morales-Gabardino JA, Redondo-Lobato L Buitrago-Ramírez F. Análisis de tiempos de las unidades medicalizadas de emergencia en la atención a los accidentes de tráfico en Extremadura. Emergencias (Madr). 2018;30(4):265-7.

11 Morales-Gabardino JA, Redondo-Lobato L, Buitrago-Ramírez F. Variables predictoras de víctimas graves, críticas o fallecidas en los accidentes de tráfico en Extremadura. Rev Esp Salud Pública. 2019 Nov;93(93):e201911069.

12 Lee J, Abdel-Aty M, Cai Q, Wang L. Effects of emergency medical services times on traffic injury severity: A random effects ordered probit approach. Traffic Inj Prev. 2018;19(6):57781.
13 Lovely R, Trecartin A, Ologun G, Johnston A, Svintozelskiy S, Vermeylen F, et al. Injury Severity Score alone predicts mortality when compared to EMS scene time and transport time for motor vehicle trauma patients who arrive alive to hospital. Traffic Inj Prev. 2018; 19(suppl 2):S167-S168. http://doi: https://doi. org/10.1080/15389588.2018.1532217.

14 Nehme Z, Andrew E, Smith K. Factors influencing the timeliness of emergency medical service response to time critical emergencies. Prehosp Emerg Care. 2016 NovDec;20(6):783-91.

15 Schwartz J, Dreyer RP, Murugiah K, Ranasinghe I. Contemporary prehospital emergency medical services response times for suspected stroke in the United States. Prehosp Emerg Care. 2016 Sep-Oct;20(5):560-5.

16 González RP, Cummings GR, Phelan HA, Mulekar MS, Rodning CB. Does increased emergency medical services prehospital time affect patient mortality in rural motor vehicle crashes? A statewide analysis. Am J Surg. 2009 Jan;197(1):30-4.

17 Mell HK, Mumma SN, Hiestand B, Carr BG Holland T, Stopyra J. Emergency Medical Services Response Times in Rural, Suburban, and Urban Areas. JAMA Surg. 2017 Oct;152(10):983-4. 
18 Loftis KL, Price J, Gillich PJ. Evolution of the Abbreviated Injury Scale: 1990-2015. Traffic Inj Prev. 2018; 19(suppl 2):S109-S113. http:// doi: https://doi.org/10.1080/15389588.2018.1 512747.

19 Burt CW, McCaig LF, Valverde RH. Analysis of ambulance transports and diversions among US emergency departments. Ann Emerg Med. 2006 Apr;47(4):317-26.

20 Ono Y, Hayakawa M, Iijima H, Maekawa K, Kodate A, Sadamoto Y, et al. The response time threshold for predicting favourable neurological outcomes in patients with bystander-witnessed out-of-hospital cardiac arrest. Resuscitation. 2016 Oct;107:65-70.

21 Feero S, Hedges JR, Simmons E, Irwin L. Does out-of-hospital EMS time affect trauma survival? Am J Emerg Med. 1995 Mar;13(2):133-5.
22 Clark DE, Qian J, Sihler KC, Hallagan LD, Betensky RA. The distribution of survival times after injury. World J Surg. 2012 Jul;36(7):1562-70.

23 Sánchez-Mangas R, García-Ferrrer A, de Juan A, Arroyo AM. The probability of death in road traffic accidents. How important is a quick medical response? Accid Anal Prev. $2010 \mathrm{Jul} ; 42(4): 1048-56$.

24 Fredriksson R, Bylund PO, Oman M. Fatal Vehicle-to-Bicyclist Crashes in Sweden - an In-Depth Study of injuries and vehicle sources. Ann Adv Automot Med. 2012;56:25-30.

25 Yang CS, Chen SC, Yang YC, Huang LC, Guo HR, Yang HY. Epidemiology and patterns of facial fractures due to road traffic accidents in Taiwan: A 15-year retrospective study. Traffic Inj Prev. 2017 Oct;18(7):724-9.
26 Blackwell TH, Kaufman JS. Response time effectiveness: comparison of response time and survival in an urban emergency medical services system. Acad Emerg Med. 2002 Apr;9(4):288-95.

27 Jaja BN, Eghwrudjakpor PO. Effect of demographic and injury etiologic factors on intensive care unit mortality after severe head injury in a low middle income country. Ann Afr Med. 2014 Oct-Dec;13(4):204-9.

28 Dong C, Clarke DB, Yan X, Khattak A, Huang B. Multivariate random-parameters zero-inflated negative binomial regression model: an application to estimate crash frequencies at intersections. Accid Anal Prev. 2014 Sep;70:320-9. 